\title{
A NOVEL ACIDOPHILIC, THERMOPHILIC IRON AND SULFUR-OXIDIZING ARCHAEON ISOLATED FROM A HOT SPRING OF TENGCHONG, YUNNAN, CHINA
}

\author{
Jiannan Ding ${ }^{1,2}$, Ruiyong Zhang ${ }^{1}$, Yizun Yu ${ }^{2}$, Decai Jin ${ }^{1}$, Changli Liang ${ }^{1}$, Yang Yi ${ }^{1}$, Wei Zhu ${ }^{1}$, Jinlan Xia ${ }^{1 *}$
}

${ }^{1}$ Key Laboratory of Biometallurgy of Ministry of Education of China, School of Minerals Processing and Bioengineering, Central South University, Changsha, Hunan 410083, China; ${ }^{2}$ Biological Resources Institute, Jiangxi Academy of Sciences, Nanchang, Jiangxi 330029, China.

Submitted: January 11, 2010; Returned to authors for corrections: February 08, 2010; Approved: January 13, 2011.

\begin{abstract}
A novel thermoacidophilic iron and sulfur-oxidizing archaeon, strain YN25, was isolated from an in situ enriched acid hot spring sample collected in Yunnan, China. Cells were irregular cocci, about 0.9-1.02 $\mu \mathrm{m} \times 1.0-1.31 \mu \mathrm{m}$ in the medium containing elemental sulfur and 1.5-2.22 $\mu \mathrm{m} \times 1.8-2.54 \mu \mathrm{m}$ in ferrous sulfate medium. The ranges of growth and $\mathrm{pH}$ were 50-85 (optimum 65) and $\mathrm{pH}$ 1.0-6.0 (optimum 1.5-2.5). The acidophile was able to grow heterotrophically on several organic substrates, including various monosaccharides, alcohols and amino acids, though the growth on single substrate required yeast extract as growth factor. Growth occurred under aerobic conditions or via anaerobic respiration using elemental sulfur as terminal electron acceptor. Results of morphology, physiology, fatty acid analysis and analysis based on 16S rRNA gene sequence indicated that the strain YN25 should be grouped in the species Acidianus manzaensis. Bioleaching experiments indicated that this strain had excellent leaching capacity, with a copper yielding ratio up to $79.16 \%$ in $24 \mathrm{~d}$. The type strain YN25 was deposited in China Center for Type Culture Collection (=CCTCCZNDX0050).
\end{abstract}

Key words: isolation, identification, Acidianus manzaensis, bioleaching

\section{INTRODUCTION}

It is well known that bioleaching, recovering metals from low-grade sulfidic ores by microorganisms, has developed into a successful commercial biotechnology. In many cases, it offers environmental and technical advantages over other available technologies $(13,21)$. This process is driven by consortia of chemolithotrophic iron and sulfur-oxidizing bacteria and archaea that are ubiquitous at sites of mineral oxidation. The most studied acidophilic metal sulfide oxidizing microorganisms belong to the mesophilic and moderately thermophilic bacteria. Thermophilic and acidophilic sulfur/iron oxidizers dominating at a temperature range of 40-60 are the typically rod-shaped, Sulfobacillus species (15, 22), although

*Corresponding Author. Mailing address: Key Laboratory of Biometallurgy of Ministry of Education, School of Minerals Processing and Bioengineering, Central South University, 932 Lushang Road, Changsha, Hunan 410083, China.; E-mail: jiannanding@ yahoo.cn / jlxia@ mail.csu.edu.cn

Jiannan Ding and Ruiyong Zhang are both first author 
other species, such as Leptospirillum ferriphilum Acidimicrobium ferrooxidans, Acidithiobacillus caldus, and Hydrogenobacter acidophilus, are also commonly present (15, 19, 33, 34). Thermophilic sulfur/iron oxidizers, which thrive above 60, usually belong to Archaea domain, genera Sulfolobus, Acidianus, or Metallosphaera (15, 22, 32).

Biological regeneration of $\mathrm{FeP}^{3+\mathrm{P}}$ from $\mathrm{FeP}^{2+\mathrm{P}}$ is the key to chemical attack of metal sulfides. However, biooxidation of reduced inorganic sulfur compounds (RISCs) is also important to prevent the accumulation of passivating sulfur particulate on metal surfaces that can limit metal mobilization rates. Thermoacidophiles grow at temperatures (60-85 $\square$ ) where mesoacidophilic or morderate biocatalysts (or contaminants from nonsterile substrates) are not able to exist, and where passivation from RISCs is nearly eliminated, lead to more effective leaching rates (23).

Sulfur-oxidizing thermoacidophilic archaea Acidianus brierleyi was firstly isolated from an acidic thermal spring in Yellowstone National Park, Wyoming, USA (2, 26), whose excellent ferrous oxidation ability revealed a potential in industrial application. The archaeon demonstrated a remarkable capacity in chalcopyrite bioleaching (the most refractory primary copper sulfide), which possessed a significant advantage over mestrophic leaching process.

This study focused on screening of thermophilic microorganisms that oxidize iron and/or sulfur compounds from hot acidic water samples. Strain YN25, a novel thermophilic iron and sulfur-oxidizing archaeon, from a hot spring (> 80) located on Tengchong, Yunnan, China, was identified as Acidianus manzaensis and its iron and sulfur oxidation and chalcopyrite leaching ability has been further investigated.

\section{MATERIALS AND METHODS}

\section{Microbial enrichment and Isolation}

The water samples from a hot spring located in
Tengchong were in situ enriched by medium A with an initial $\mathrm{pH} \quad 1.8$ at 70 . The medium $\mathrm{A}$ contains $\left(\mathrm{g} \cdot \mathrm{LP}^{-1 \mathrm{P}}\right)$ : $\left(\mathrm{NHB}_{4 \mathrm{~B}}\right) \mathrm{B}_{2 \mathrm{~B}} \mathrm{SOB}_{4 \mathrm{~B}} \quad(1.5), \quad \mathrm{MgSOB}_{4 \mathrm{~B}} \cdot 7 \mathrm{HB}_{2 \mathrm{~B}} \mathrm{O} \quad(0.25)$, $\mathrm{KHB}_{2 \mathrm{~B}} \mathrm{POB}_{4 \mathrm{~B}}(0.25)$, Yeast Extract (0.1), FeSOB ${ }_{4 \mathrm{~B}} \cdot 7 \mathrm{HB}_{2 \mathrm{~B}} \mathrm{O}$ (5-20), $\mathrm{pH}$ 1.8. Two thermophilic microbial cultures (one of which is Strain YN25) were obtained. by serial dilution method.

\section{Growth conditions}

Strain YN25 was cultivated in basic salts (medium A with $\mathrm{FeSOB}_{4 \mathrm{~B}}$ as energy source and modified $9 \mathrm{~K}$ with $\mathrm{SP}^{\mathrm{OP}}$, $\mathrm{NaB}_{2 \mathrm{~B}} \mathrm{SB}_{2 \mathrm{~B}} \mathrm{OB}_{3}$ Bor $\mathrm{KB}_{2 \mathrm{~B}} \mathrm{OB}_{6 \mathrm{~B}} \mathrm{SB}_{4}$ as energy source), trace elements (7) and $0.02 \%$ YE. Modified $9 \mathrm{~K}$ contains $\left(\mathrm{g} \cdot \mathrm{LP}^{-1 \mathrm{P}}\right)$ : $\left(\mathrm{NHB}_{4 \mathrm{~B}}\right) \mathrm{B}_{2 \mathrm{~B}} \mathrm{SOB}_{4}{ }_{\mathrm{B}}(3.0), \quad \mathrm{KHB}_{2 \mathrm{~B}} \mathrm{POB}_{4 \mathrm{~B}} \quad(0.5), \quad \mathrm{KCl} \quad(0.1)$, $\mathrm{MgSOB}_{4 \mathrm{~B}} \cdot 7 \mathrm{HB}_{2 \mathrm{~B}} \mathrm{O}(0.5)$ and $\mathrm{Ca}\left(\mathrm{NOB}_{3 \mathrm{~B}}\right) \mathrm{B}_{2} \mathrm{~B}$ (0.01). Trace elements $\left(\mathrm{mg} \cdot \mathrm{LP}^{-1 \mathrm{P}}\right)$ compose: $\mathrm{FeClB}_{3 \mathrm{~B}} \cdot 6 \mathrm{HB}_{2 \mathrm{~B}} \mathrm{O} \quad(11.0)$, $\mathrm{CuSOB}_{4 \mathrm{~B}} \cdot 5 \mathrm{HB}_{2 \mathrm{~B}} \mathrm{O}(0.5), \mathrm{NaB}_{2 \mathrm{~B}} \mathrm{SOB}_{4}(50), \mathrm{HB}_{3 \mathrm{~B}} \mathrm{BOB}_{3}(2.0)$, $\mathrm{MnSOB}_{4 \mathrm{~B}} \quad(2.0), \quad \mathrm{NaB}_{2 \mathrm{~B}} \mathrm{MoOB}_{4 \mathrm{~B}} \cdot 2 \mathrm{HB}_{2 \mathrm{~B}} \mathrm{O} \quad(0.8)$, $\mathrm{CoClB}_{2 \mathrm{~B}} \cdot 6 \mathrm{HB}_{2 \mathrm{~B}} \mathrm{O} \quad(0.6), \quad \mathrm{ZnSOB}_{4 \mathrm{~B}} \cdot 7 \mathrm{HB}_{2 \mathrm{~B}} \mathrm{O} \quad(0.9) \quad$ and $\mathrm{NaB}_{2 \mathrm{~B}} \mathrm{SeOB}_{4 \mathrm{~B}}(0.1)$. The $\mathrm{pH}$ of medium $9 \mathrm{~K}-\mathrm{S}^{0}$ and medium A$\mathrm{FeSO}_{4}$ were adjusted with $1 \mathrm{M}$ sulfuric acid to 2.5 and 2.0, respectively. Cultures were incubated in rotary shakers at the indicated temperatures.

The optimum temperature and $\mathrm{pH}$ were detected by temperature- and $\mathrm{pH}$ - controlled experiments in $250 \mathrm{~mL}$ shaking flasks with $100 \mathrm{~mL}$ medium. The purified strain was inoculated into liquid medium with a final cell density of $1 \times 10 \mathrm{P}^{6 \mathrm{P}}$ cells $\mathrm{mLP}^{-1 \mathrm{P}}$. The temperature optimization was conducted under, initial $\mathrm{pH} 1.5$ in medium $\mathrm{A}_{-} \mathrm{FeSOB}_{4 \mathrm{~B}}$ and $\mathrm{pH}$ 2.5 in $9 \mathrm{~K}-\mathrm{SP}^{\mathrm{OP}}$, while the initial $\mathrm{pH}$ test was carried out at a constant temperature at $65^{\circ} \mathrm{C}$, which was given in the former one. The cell densities of cultures in the flasks were monitored by a cell counting chamber directly.

To determine the optimal concentration of YE, a series of tests with the following different concentration of YE $(w / v)$ : $0.005 \%, 0.01 \%, 0.015 \%, 0.02 \%, 0.025 \%, 0.03 \%, 0.035 \%$, $0.04 \%, 0.045 \%, 0.05 \%, 0.06 \%, 0.07 \%, 0.08 \%, 0.085 \%, 0.09 \%$, 
$0.1 \%$, were implemented.

\section{Microscopy}

The morphology and motility of the strain YN25 were observed with optical microscope (Olympus CX-31). Surface micro-structural features of the cells in the logarithm growth phase were examined with scanning electron microscope (SEM, JEOL JSM-6360 LV), following fixation, dehydration and critical point drying of samples (12).

\section{S rRNA gene profiling}

Chromosomal DNA was purified in accordance with the manufacturer's instructions by DNA extraction kit (Tiangen Biotech), and was used as a template in PCR. The 16S rRNA genes of YN25 were amplified by polymerase chain reaction (PCR) using the forward primer 21F: 5'TTCCGGTTGATCCTG-3' and reverse primer Ar958R: 5'TCCGGCGTTGAGTCC-3' (4). The PCR program was $94^{\circ} \mathrm{C}$ for $3 \mathrm{~min}$, followed by 30 cycles of $94^{\circ} \mathrm{C}$ for $30 \mathrm{~s}, 52^{\circ} \mathrm{C}$ for 30 $\mathrm{s}$, and $72^{\circ} \mathrm{C}$ for $60 \mathrm{~s}$, and finally $72^{\circ} \mathrm{C}$ for $10 \mathrm{~min}$. PCR products of the expected size (approximately $1.5 \mathrm{~kb}$ ) were excised from $1.0 \%$ agarose gels and purified with the purification columns (Promega), following the manufacturer's recommendations. The PCR products were ligated to the pGEM-T vector and transformed into Escherichia coli DH5 $\alpha$. The white colonies on the Luria-Bertani (LB) plates containing ampicillin $\left(100 \mu \mathrm{g} \cdot \mathrm{mLP}^{-1}\right), \mathrm{X}$-gal $\left(20 \mathrm{mg} \cdot \mathrm{mLP}^{-1}\right)$ and IPTG (16 $\mathrm{mg} \cdot \mathrm{mLP}^{-1}$ ) (31) were selected and sent to Sunbiotech Co.Ltd for sequencing. The nucleotide sequence of the inserts was determined by cycle sequencing with an ABI PRISM Big Dye terminator cycle sequencing Ready Reaction kit (Applied Biosystems, Foster City, California) and run in an ABI PRISM 3700 DNA analyzer (Applied Biosystems).

The phylogenetic tree showing the relationship of YN25 to other Acidianus species was elaborated with related sequences obtained from public databases (http://www.ncbi.nlm.nih.gov/). The sequences were aligned with YN25 sequence using Clustal X 1.80, which was used to make a distance matrix, followed by a neighbor-joining tree. Bootstrap analysis was carried out on 1000 replicates input data sets, and Phylogenetic trees were generated by Treeview software MEGA 3.1.

\section{Nutrition growth}

In Chemoorganotrophic growth tests, the following organic compounds were tested without $\mathrm{FeSOB}_{4 \mathrm{~B}}$ or $\mathrm{SP}^{\mathrm{OP}}$, which were: Yeast extract (YE), Casamino acids, Tryptone, Dglucose, Maltose, Sucrose, Lactose, Starch, Sorbitol, Galactose, Fructose, Xylose, Mannitol, Serine, Cysteine, Tyrosine, Arginine, Tryptophan, Phenylalanine, Histidine, Methionine, Leucine, Threonine, Glycine, Valine, Glutamine. The concentrations of YE, Casamino acids and Tryptone were $0.2,0.1$ and $0.2 \mathrm{~g} \cdot \mathrm{LP}^{-1 \mathrm{P}}$, respectively. The other test substrates concentration was $1.0 \mathrm{~g} \cdot \mathrm{LP}^{-1 \mathrm{P}}$. The isolate was grown in $9 \mathrm{~K}$ base medium with the culture maintained at $\mathrm{pH} 2.5,65^{\circ} \mathrm{C}$. Growth was estimated by detecting the total protein concentration after incubation for $72 \mathrm{~h}(8)$.

Medium A-FeSOB $4 \mathrm{~B}$ and 9K-base medium were used for chemomixotrophic growth. $30 \mathrm{~g} \cdot \mathrm{LP}^{-1 \mathrm{P}} \mathrm{FeSOB}_{4 \mathrm{~B}} \cdot 7 \mathrm{HB}_{2 \mathrm{~B}} \mathrm{O}$ for medium A, $10 \mathrm{~g} \cdot \mathrm{LP}^{-1 \mathrm{P}} \mathrm{SP}^{0 \mathrm{P}}, \mathrm{NaB}_{2 \mathrm{~B}} \mathrm{SB}_{2 \mathrm{~B}} \mathrm{OB}_{3}$ B or $2 \mathrm{~g} \cdot \mathrm{LP}^{-1 \mathrm{P}}$ $\mathrm{KB}_{2 \mathrm{~B}} \mathrm{OB}_{6 \mathrm{~B}} \mathrm{SB}_{4 \mathrm{~B}}$ for $9 \mathrm{~K}$-base medium, were added as energy. The only organic source was $0.2 \mathrm{~g} \cdot \mathrm{LP}^{-1 \mathrm{P}} \mathrm{YE}$.

Chemoautotrophic growth tests were performed in the same way without YE.

\section{Anaerobic growth}

Anaerobic growth was tested in anaerobic tank with of 21 $\mathrm{kPa} \mathrm{COB}_{2 \mathrm{~B}}$ and $79 \mathrm{kPa} \mathrm{NB} \mathrm{N}_{2}$ containing basic salts, trace elements and YE $\left(0.2 \mathrm{~g} \cdot \mathrm{LP}^{-1}\right)$ with elemental sulfur $\left(10 \mathrm{~g} \cdot \mathrm{LP}^{-1 \mathrm{P}}\right)$ or ferric iron $\left(10 \mathrm{mmol} \cdot \mathrm{LP}^{-1}\right)$ в. The initial inoculation concentration was adjusted to $1 \times 10 \mathrm{P}^{6 \mathrm{P}}$ cells $\cdot \mathrm{mLP}^{-1}$ with cells washed in basal salts medium thoroughly. To assure the anaerobic circumstance, the media were sprinkled with $\mathrm{NB}_{2 \mathrm{~B}}$ for $5 \mathrm{~min}$ and oxygen indicators were placed in the anaerobic 
tank. To monitor the sulfate reduction reaction lead acetate papers was used in the anaerobic tank. Concentration of total iron was analyzed by atomic absorption spectrometry, and that of ferric iron was calculated by the concentrations of total iron and ferrous iron (34). Cell growth was determined by the protein concentration started from the stationary phase.

\section{Sensitivity to antibiotics and tolerance to heavy metals}

The antibiotic sensitivity to antibiotics and tolerance to several heavy metals of strain YN25 were monitored in sulfurcontaining media (as described above) different concentrations of ampicillin, chloramphenicol, kanamycin, rifampin, tetracycline and gentamicin (35) and varying concentrations of $\mathrm{CuSOB}_{4 \mathrm{~B}} \cdot 5 \mathrm{HB}_{2 \mathrm{~B}} \mathrm{O}, \quad \mathrm{NiSOB}_{4 \mathrm{~B}} \cdot 6 \mathrm{HB}_{2 \mathrm{~B}} \mathrm{O}, \quad \mathrm{ZnSOB}_{4 \mathrm{~B}} \cdot 7 \mathrm{HB}_{2 \mathrm{~B}} \mathrm{O}$, $\mathrm{AlB}_{2 \mathrm{~B}}\left(\mathrm{SOB}_{4 \mathrm{~B}}\right) \mathrm{B}_{3 \mathrm{~B}} \cdot 18 \mathrm{HB}_{2 \mathrm{~B}} \mathrm{O}, \quad \mathrm{CoSOB}_{4 \mathrm{~B}} \cdot 7 \mathrm{HB}_{2 \mathrm{~B}} \mathrm{O}$ and $3 \mathrm{CdSOB}_{4 \mathrm{~B}} \cdot 8 \mathrm{HB}_{2 \mathrm{~B}} \mathrm{O}$ (33). Growth was estimated by detecting the total protein concentration in $72 \mathrm{~h}$ of incubation (8).

\section{Whole-cell lipid fatty acid analysis}

Cells of strain YN25 were harvested by centrifugation, and then transferred directly to a screw-cap vial. The fatty acid methyl esters (FAMEs) were obtained by methylation, saponification and extraction, as described previously (18). The separation of FAMEs was performed by a gas chromatography (model DNAI 6500-HR) equipped with a flame ionization detector (FID) and a 25-m fusedsilica column cross-linked with an SE-30 liquid phase (SGE; Ringwood, Victoria, Australia), in a carrier gas $\left(\mathrm{HB}_{2 \mathrm{~B}}\right)$ flow rate of $1.2 \mathrm{~mL} \cdot \mathrm{minP}^{-1 \mathrm{P}}$, an injector temperature of 250, a detector temperature of 300 , and an oven temperature program of 120 to 280 at $4 \mathrm{minP}^{-1 \mathrm{P}}$. The FAMEs were identified by comparison with the retention times of standards and their proportions were calculated on a Chromatography Data System.

\section{Bioleaching of chalcopyrite}

Chalcopyrite used in this experiment was provided by Institute of Mineral Processing Engineering, School of
Resources Processing and Bioengineering, Central South University, China. The chalcopyrite contains $30.6 \%$ of $\mathrm{Cu}$, $22.64 \%$ of $\mathrm{Fe}, 29.6 \%$ of $\mathrm{S}, 1.72 \%$ of $\mathrm{Zn}$ and $8.95 \%$ of $\mathrm{Pb}$.

Bioleaching tests were carried out in $250 \mathrm{~mL}$ flasks with $100 \mathrm{~mL}$ 9K-base medium, in a mineral concentration of $3 \%$ $(\mathrm{w} / \mathrm{v})$. The initial concentration of YN25 was $2-4 \times 10^{6}$ cells $\cdot \mathrm{mLP}^{-1}$, and all the experiments were carried out in triclicates. Abiotic controls were also implemented at same conditions by replacing the bacterial inoculum with an equal volume of medium. Aliquots of solution were sampled, and the concentration of $\mathrm{CuP}^{2+}{ }^{2}$ was determined by atomic absorption spectrometry (Hatichi Z-8000). The evaporated water in the medium was supplemented with sterilized deionized water.

\section{RESULTS AND DISSCUSSION}

\section{Morphological characterization}

The cell morphology was similar to other members in the order of Sulfolobales, with slightly aspherical shape (Figure 1). The cell shape and size were significantly varied in different energy resource. The dimension of strain YN25 was about 0.9$1.02 \mu \mathrm{m} \times 1.0-1.31 \mu \mathrm{m}$ in the medium containing elemental sulfur and 1.5-2.22 $\mu \mathrm{m} \times 1.8-2.54 \mu \mathrm{m}$ in the medium containing ferrous sulfate. The cell surface was crimpy but smooth in medium $9 \mathrm{~K}-\mathrm{SP}^{0}$ while its counterpart in medium $\mathrm{A}-\mathrm{FeSOB}_{4 \mathrm{~B}}$ was round and, rough.

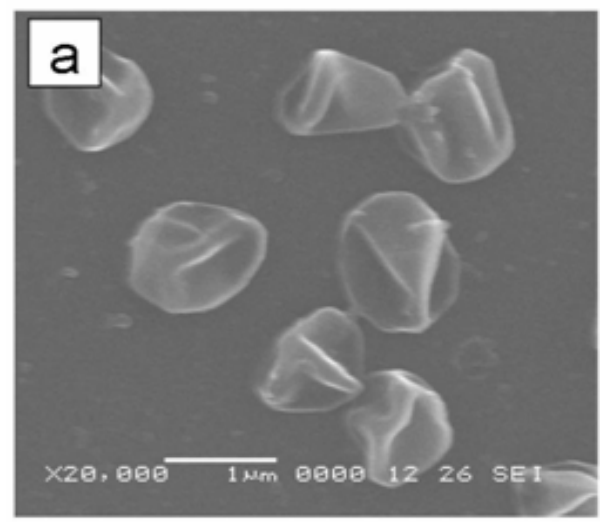




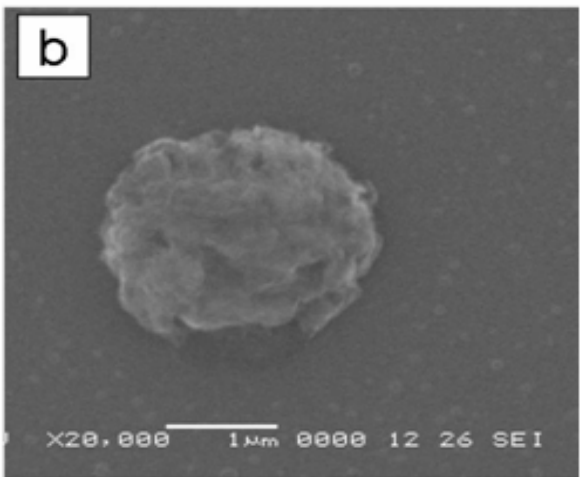

Figure 1. Scanning electron micrographs of strain YN25 cultivated chemoautotrophically on liquid medium at 65 with Sulfur (a) and Ferrous iron (b).

\section{Growth conditions}

The strain YN25 was able to grow on several organic substrates, including various monosaccharides, alcohols and amino acids (Table 1), while no growth was observed when it was cultivated in inorganic substrates alone. However, in the presence of YE, peptone or other organics, the strain YN25 could grew well in inorganic substrates. These results suggested that strain YN25 is a facultative autotrophic microorganism, in absence of the evidence from carbon isotope experiment.

Bacterial growth was observed at temperatures between 50 and 85 , with an optimum status at 65 (Figure 2a). No growth occurred when temperature was below 30 or above 90 (data not shown). Growth occurred at initial $\mathrm{pH}$ of 1.0 to 5.0, with an optimum $\mathrm{pH}$ of 1.5 in the medium $\mathrm{A}-\mathrm{FeSOB}_{4}$, and, at initial $\mathrm{pH}$ of 1.0 to 6.0 with an optimum $\mathrm{pH}$ of 2.5 in $9 \mathrm{~K}-\mathrm{SP}^{\mathrm{OP}}$ medium (Figure 2b).

Table 1. Growth characteristics of strain YN25 under different nutritional conditions

\begin{tabular}{|c|c|c|c|}
\hline $\begin{array}{c}\text { Growth condition or } \\
\text { substrate }\end{array}$ & $\begin{array}{c}\text { Protein concentration } \\
\left(\mu \mathrm{g} \cdot \mathrm{mLP} \mathbf{P}^{-1 \mathrm{P}}\right)\end{array}$ & Growth condition or substrate & $\begin{array}{c}\text { Protein concentration } \\
\left(\mu \mathrm{g} \cdot \mathrm{mL} \mathbf{P}^{-1 \mathrm{P}}\right)\end{array}$ \\
\hline Chemoorganotrophic & & Glycine & $1.06 \pm 0.18$ \\
\hline Yeast extract & $2.95 \pm 0.23 \mathrm{~Pa}$ & Valine & $0.97 \pm 0.25$ \\
\hline Casamino acids & $0.26 \pm 0.14$ & Glutamine & $0.32 \pm 0.21$ \\
\hline Tryptone & $3.02 \pm 0.33$ & Chemomixotrophic & \\
\hline Glucose & $2.97 \pm 0.36$ & SP0P plus organic substrate & \\
\hline Sucrose & $2.33 \pm 0.39$ & Yeast extract & $2.26 \pm 0.23 \mathrm{PbP}$ \\
\hline Sorbitol & $0.00 \pm 0.17$ & Casamino acids & $0.34 \pm 0.22$ \\
\hline Galactose & $2.10 \pm 0.17$ & Tryptone & $2.46 \pm 0.32$ \\
\hline Mannitol & $0.15 \pm 0.23$ & $\mathrm{FeP} 2+\mathrm{P}$ plus organic substrate & \\
\hline Xylose & $0.00 \pm 0.13$ & Yeast extract & $1.95 \pm 0.29$ \\
\hline Lactose & $1.06 \pm 0.25$ & Casamino acids & $0.18 \pm 0.20$ \\
\hline Starch & $1.82 \pm 0.26$ & Tryptone & $1.79 \pm 0.30$ \\
\hline Maltose & $2.19 \pm 0.30$ & NaB2BSB2BOB3B & \\
\hline Fructose & $0.20 \pm 0.13$ & Yeast extract & $0.35 \pm 0.39 \mathrm{PcP}$ \\
\hline Serine & $0.00 \pm 0.18$ & Casamino acids & $0.10 \pm 0.12$ \\
\hline Cysteine & $0.00 \pm 0.14$ & Tryptone & $0.37 \pm 0.23$ \\
\hline Tyrosine & $0.00 \pm 0.22$ & KB2BOB6BSB4B & \\
\hline Arginine & $0.33 \pm 0.15$ & Yeast extract & $1.33 \pm 0.22$ \\
\hline Tryptophan & $0.00 \pm 0.20$ & Casamino acids & $0.13 \pm 0.10$ \\
\hline Phenylalanine & $0.16 \pm 0.23$ & Tryptone & $1.41 \pm 0.25$ \\
\hline Histidine & $0.13 \pm 0.15$ & Chemoautotrophic & \\
\hline Methionine & $0.18 \pm 0.14$ & $\mathrm{SP} 0$ & $0.14 \pm 0.08$ \\
\hline Leucine & $0.86 \pm 0.19$ & $\mathrm{NaB} 2 \mathrm{BSB} 2 \mathrm{BOB} 3$ & $0.03 \pm 0.11$ \\
\hline Threonine & $0.13 \pm 0.11$ & KB2BOB6BSB4 & $0.19 \pm 0.24$ \\
\hline
\end{tabular}



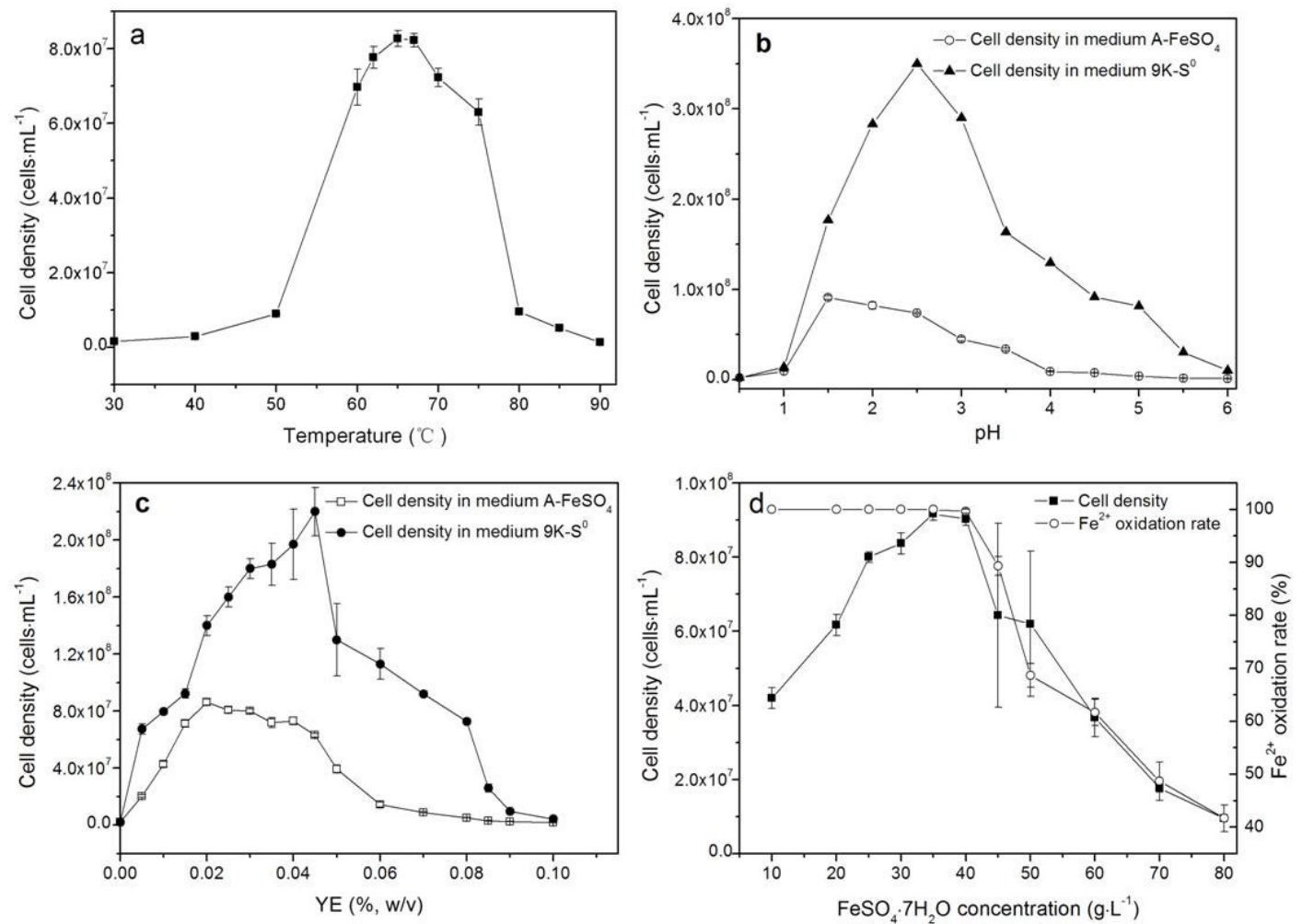

Figure 2. Effect of temperature (Figure 2a), pH (Figure 2b), YE (Figure 2c) and FeP ${ }^{2+\mathrm{P}}$ (Figure 2d) on growth of strain YN25. Each data point shows the mean of triplicate tests

The growth of strain YN25 at different YE concentrations was determined. The optimum concentration of YE for YN25 in medium A-FeSO ${ }_{4}$ and $9 \mathrm{~K}-\mathrm{S}^{0}$ was $0.02 \%$ and $0.45 \%$, respectively. Growth was strongly inhibited by the presence of YE in concentration above $0.10 \%$ (Figure $2 \mathrm{c}$ ), which may act as growth factors in the process.

It can be seen from Figure $2 \mathrm{~d}, \mathrm{FeP}^{2+\mathrm{P}}$ was completed oxidized after $35 \mathrm{~h}$ when $\mathrm{FeSOB}_{4 \mathrm{~B}} \cdot 7 \mathrm{HB}_{2 \mathrm{~B}} \mathrm{O}$ concentration varied between 10-40 $\mathrm{g} \cdot \mathrm{LP}^{-1}$, and and largest cell density was gained with a ferrous iron concentration of $35 \mathrm{~g} \cdot \mathrm{LP}^{-1 \mathrm{P}}$. Cell density and $\mathrm{FeP}^{2+\mathrm{P}}$ oxidizing activity significantly decreased when $\mathrm{FeSOB}_{4 \mathrm{~B}} \cdot 7 \mathrm{HB}_{2 \mathrm{~B}} \mathrm{O}$ concentration was above $45 \mathrm{~g} \cdot \mathrm{LP}^{-1}$, while cells reproduction was reduced in a $\mathrm{FeSOB}_{4 \mathrm{~B}} \cdot 7 \mathrm{HB}_{2 \mathrm{~B}} \mathrm{O}$ concentration below $25 \mathrm{~g} \cdot \mathrm{LP}^{-1 \mathrm{P}}$. Generally, compared with other iron-oxidizing bacteria, strain YN25 had higher ferrous iron oxidizing activity $(2,8,11,33,34)$.
The sulfur oxidizing activity of strain YN25 was determined in the optimum conditions (initial $\mathrm{pH} 2.5,10 \mathrm{~g} \cdot \mathrm{L}^{-1}$ $\left.\mathrm{S}^{0}, 0.2 \mathrm{~g} \cdot \mathrm{L}^{-1} \mathrm{YE}\right)$, where the concentration of $\mathrm{SOB}_{4 \mathrm{~PB}}{ }^{2-} \mathrm{P}$ reached $25 \mathrm{~g} \cdot \mathrm{L}^{-1}$ after 70 hours' cultivation.

\section{Anaerobic Metabolisms}

The biggest differents in characteristics of genus Acidianus were the two chemolithotrophic cultivations. Under aerobic conditions, Acidianus grew aerobically with $\mathrm{OB}_{2 \mathrm{~B}}$ as the final electron acceptor. At extremely anaerobic conditions, Acidianus grew anaerobically, forming $\mathrm{HB}_{2 \mathrm{~B}} \mathrm{~S}$ or $\mathrm{FeP}^{2+\mathrm{P}}$, in which $\mathrm{HB}_{2 \mathrm{~B}}$ or organic components served as electron donor, and $\mathrm{SP}^{0 \mathrm{P}}$ or $\mathrm{FeP}^{3+\mathrm{P}}$ served as the final electron acceptor $(16,20$, 26). Electron donor and acceptor were important basis for this archaea system classification.

YN25 has high elemental sulfur reducing capacity at 
extremely anaerobic conditions, generating a significant amount of $\mathrm{HB}_{2 \mathrm{~B}} \mathrm{~S}$. In the anaerobic experiment, the lead acetate filter paper suspended in the experimental bottle began to change color after $40 \mathrm{~h}$ cultivation, and became completely black after $60 \mathrm{~h}$. Meanwhile, we found strain YN25 can not reduce the ferric iron. At anaerobic conditions, YN25 shared the same electron donor and acceptor, $\mathrm{HB}_{2 \mathrm{~B}}$ and $\mathrm{SP}^{0 \mathrm{P}}$, respectively, with $A$. infernus, A. ambivalens, A. brierleyi and A. tenchongensis. A. manzaensis, and had the same electron acceptor of ferric iron as A. sulfidivorans, but different electron donor, which were $\mathrm{HB}_{2 \mathrm{~B}}$ and $\mathrm{HB}_{2 \mathrm{~B}} \mathrm{~S}$, respectively (Table 2). Based on the characterization of anaerobic metabolism, strain YN25 had the same electron donor with A. manzaensis ATCC BAA 1057 but clear differences in electron acceptor (32).

Table 2. Main physiological, biophysical and phylogenetic traits and of isolate YN25 and members of the genus Acidianus

\begin{tabular}{|c|c|c|c|c|c|c|c|}
\hline & YN25 & A. manzaensis & A. infernus & A. ambivalens & A.brierleyi & A. tenchongensis & A. sulfidivorans \\
\hline $\begin{array}{l}\text { Growth } \\
\text { temperature } \\
\text { (optimum) }\end{array}$ & $\begin{array}{c}50-85 \\
(65)\end{array}$ & $\begin{array}{c}60-90 \\
(80)\end{array}$ & $\begin{array}{c}65-96 \\
(90)\end{array}$ & $\begin{array}{c}70-87 \\
(80)\end{array}$ & $\begin{array}{c}45-75 \\
(70)\end{array}$ & $\begin{array}{c}60-75 \\
(70)\end{array}$ & $\begin{array}{c}45-83 \\
(74)\end{array}$ \\
\hline $\begin{array}{l}\text { Growth pH } \\
\text { (optimal pH) }\end{array}$ & $\begin{array}{c}1.0-6.0 \\
(1.5,2.5)\end{array}$ & $\begin{array}{c}1.0-5.0 \\
(1.2-1.5)\end{array}$ & $1.0-5.5(2.0)$ & $1.0-3.5(2.5)$ & $1.0-6.0(1.5-2.0)$ & $1.0-5.5(1.5-2.0)$ & $0.35-3.0(0.8-1.4)$ \\
\hline Electron donor & $\begin{array}{l}\mathrm{HB}_{2 \mathrm{~B}}, \mathrm{SP}^{0 \mathrm{P}}, \mathrm{FP}^{2+\mathrm{P}} \\
\text { and organic } \\
\text { compounds (Yeast } \\
\text { extract, peptone, } \\
\text { tryptone, } \\
\text { cassamino acid) }\end{array}$ & $\begin{array}{c}\mathrm{HB}_{2 \mathrm{~B}}, \mathrm{SP}^{0 \mathrm{P}}, \mathrm{FeP}^{2+\mathrm{P}} \\
\text { and organic } \\
\text { compounds } \\
\text { (Yeast } \\
\text { extract,peptone, } \\
\text { tryptone, } \\
\text { cassamino acid) }\end{array}$ & $\mathrm{HB}_{2 \mathrm{~B}}, \mathrm{SP}^{0 \mathrm{P}}$ & $\mathrm{HB}_{2 \mathrm{~B}}, \mathrm{SP}^{0 \mathrm{P}}$ & $\begin{array}{c}\mathrm{HB}_{2 \mathrm{~B}}, \mathrm{SP}^{0 \mathrm{P}}, \mathrm{FP}^{2+\mathrm{P}} \\
\text { and organic } \\
\text { compounds (Yeast } \\
\text { extract, peptone, } \\
\text { tryptone, } \\
\text { cassamino } \\
\text { acid) }\end{array}$ & $\mathrm{HB}_{2 \mathrm{~B}}, \mathrm{SP}^{0 \mathrm{P}}$ & $\begin{array}{c}\mathrm{SP}^{0 \mathrm{P}}, \mathrm{FP}^{2+\mathrm{P}} \text { and } \\
\mathrm{HB}_{2 \mathrm{~B}} \mathrm{~S}\end{array}$ \\
\hline $\begin{array}{l}\text { Electron } \\
\text { acceptor }\end{array}$ & $\mathrm{SP}^{\mathrm{OP}}$ and $\mathrm{OB}_{2 \mathrm{~B}}$ & $\mathrm{FeP}^{3+\mathrm{P}}$ and $\mathrm{OB}_{2 \mathrm{~B}}$ & $\begin{array}{l}\mathrm{SP}^{0 \mathrm{P}} \text { and } \\
\mathrm{OB}_{2 \mathrm{~B}}\end{array}$ & $\mathrm{SP}^{0 \mathrm{P}}$ and $\mathrm{OB}_{2 \mathrm{~B}}$ & $\mathrm{SP}^{0 \mathrm{P}}$ and $\mathrm{OB}_{2 \mathrm{~B}}$ & $\mathrm{SP}^{0 \mathrm{P}}$ and $\mathrm{OB}_{2 \mathrm{~B}}$ & $\mathrm{FeP}^{3+\mathrm{P}}$ and $\mathrm{OB}_{2 \mathrm{~B}}$ \\
\hline Autotrophy & $\begin{array}{c}\text { Facultative } \\
\text { autotroph }\end{array}$ & $\begin{array}{c}\text { Facultative } \\
\text { autotroph }\end{array}$ & $\begin{array}{l}\text { Obligate } \\
\text { autotroph }\end{array}$ & $\begin{array}{l}\text { Obligate } \\
\text { autotroph }\end{array}$ & $\begin{array}{l}\text { Facultative } \\
\text { autotroph }\end{array}$ & Obligate autotroph & $\begin{array}{l}\text { Obligate } \\
\text { autotroph }\end{array}$ \\
\hline $\begin{array}{l}16 \mathrm{~S} \text { rDNA } \\
\text { similarity }\end{array}$ & 1.00 & 0.99 & 0.93 & 0.93 & 0.90 & 0.90 & 0.97 \\
\hline
\end{tabular}

\section{Antibiotic sensitivity and heavy metal tolerance}

Strain YN25 was sensitive to all antibiotics except gentamicin in a limited concentration (Table 3). It presented little sensitivity to gentamicin $\left(100 \mathrm{mg} \cdot \mathrm{L}^{-1}\right)$ and high sensitivity to rifampin $\left(5 \mathrm{mg} \cdot \mathrm{L}^{-1}\right)$, tetracycline $\left(20 \mathrm{mg} \cdot \mathrm{L}^{-1}\right)$, Kanamycin $\left(50 \mathrm{mg} \cdot \mathrm{L}^{-1}\right)$, (Chloramphenicol $\left.50 \mathrm{mg} \cdot \mathrm{L}^{-1}\right)$ and Ampicillin $(50$ $\left.\mathrm{mg} \cdot \mathrm{L}^{-1}\right)$.

Generally, the strain YN25 growth was inhibited with the increase of heavy metal concentrations. $\mathrm{CoP}^{2+\mathrm{P}}, \mathrm{NiP}^{2+\mathrm{P}}$ and $\mathrm{CuP}^{2+\mathrm{P}}$ were deleterious for the strain growth However, YN25
TexhibitTed tolerance in different levels to a range of heavy metals and showed strongest resistance to $\mathrm{AlB}_{2 \mathrm{~B}}\left(\mathrm{SOB}_{4 \mathrm{~B}}\right) \mathrm{B}_{3 \mathrm{~B}} \cdot 18 \mathrm{HB}_{2 \mathrm{~B}} \mathrm{O}$ (Table 4). Growth was significantly enhacnced with 20-40 mM $\mathrm{AlB}_{2 \mathrm{~B}}\left(\mathrm{SOB}_{4 \mathrm{~B}}\right) \mathrm{B}_{3 \mathrm{~B}} \cdot 18 \mathrm{HB}_{2 \mathrm{~B}} \mathrm{O}$ and the biomass increased by $61 \%$ in the presence of $40 \mathrm{mM} \mathrm{AlB}_{2 \mathrm{~B}}\left(\mathrm{SOB}_{4 \mathrm{~B}}\right) \mathrm{B}_{3 \mathrm{~B}} \cdot 18 \mathrm{HB}_{2 \mathrm{~B}} \mathrm{O}$. In addition, low concentration of $\mathrm{ZnSOB}_{4 \mathrm{~B}} \cdot 7 \mathrm{HB}_{2 \mathrm{~B}} \mathrm{O}(<4 \mathrm{mM})$ and $3 \mathrm{CdSOB}_{4 \mathrm{~B}} \cdot 8 \mathrm{HB}_{2 \mathrm{~B}} \mathrm{O}(<0.4 \mathrm{mM})$ could slightly promote the growth of YN25. The heavy metals tolerance granted strain YN25 a special advantage in bioleaching. 
Table 3. Sensitivity of strain YN25 to antibiotics

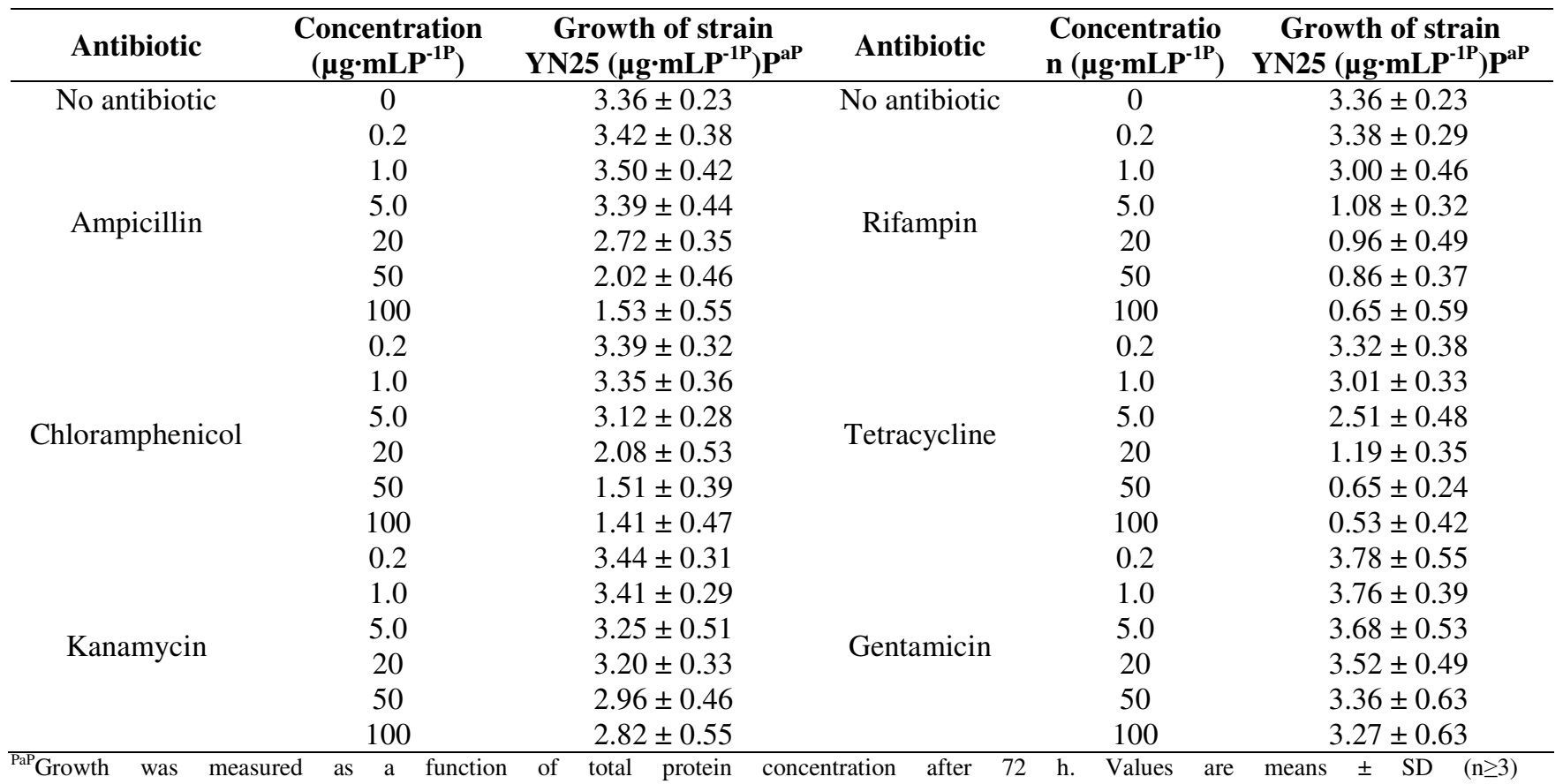

Table 4. Tolerance of the strain YN25 to some heavy metals

\begin{tabular}{|c|c|c|c|c|c|}
\hline Heavy metal & $\begin{array}{l}\text { Concentrati } \\
\text { on }(\mathbf{m M})\end{array}$ & $\begin{array}{c}\text { Growth of strain } \\
\text { YN25 }\left(\mu \mathrm{g} \cdot \mathrm{mLP}^{-1 \mathrm{P}}\right) \mathbf{P}^{\mathrm{aP}}\end{array}$ & Heavy metal & $\begin{array}{l}\text { Concentrati } \\
\text { on }(\mathbf{m M})\end{array}$ & $\begin{array}{c}\text { Growth of strain } \\
\text { YN25 }\left(\mu \mathrm{g} \cdot \mathrm{mLP}^{-1 \mathrm{P}}\right) \mathrm{P}^{\mathrm{aP}}\end{array}$ \\
\hline \multirow[t]{3}{*}{ No heavy metal } & 0 & $3.41 \pm 0.26$ & \multirow[t]{2}{*}{ No heavy metal } & & $3.41 \pm 0.26$ \\
\hline & 5 & $3.03 \pm 0.32$ & & 20 & $4.54 \pm 0.43$ \\
\hline & 10 & $2.70 \pm 0.43$ & \multirow{4}{*}{$\begin{array}{c}\mathrm{AlB}_{2 \mathrm{~B}}\left(\mathrm{SOB}_{4 \mathrm{~B}}\right) \mathrm{B}_{3 \mathrm{~B}} \\
\cdot 18 \mathrm{HB}_{2 \mathrm{~B}} \mathrm{O}\end{array}$} & 40 & $5.51 \pm 0.66$ \\
\hline \multirow{5}{*}{$\mathrm{CuSOB}_{4 \mathrm{~B}} \cdot 5 \mathrm{HB}_{2 \mathrm{~B}} \mathrm{O}$} & 20 & $1.84 \pm 0.39$ & & 80 & $3.08 \pm 0.73$ \\
\hline & 40 & $0.95 \pm 0.45$ & & 160 & $2.59 \pm 0.38$ \\
\hline & 80 & $0 . .42 \pm 0.26$ & & 320 & $2.16 \pm 0.47$ \\
\hline & 20 & $3.11 \pm 0.54$ & \multirow{5}{*}{$\begin{array}{c}\operatorname{CoSOB}_{4 \mathrm{~B}} \cdot 7 \mathrm{HB}_{2 \mathrm{~B}} \\
\mathrm{O}\end{array}$} & 1 & $1.80 \pm 0.58$ \\
\hline & 40 & $2.73 \pm 0.66$ & & 2 & $1.20 \pm 0.32$ \\
\hline \multirow{5}{*}{$\mathrm{NiSOB}_{4 \mathrm{~B}} \cdot 6 \mathrm{HB}_{2 \mathrm{~B}} \mathrm{O}$} & 80 & $1.87 \pm 0.30$ & & 4 & $1.00 \pm 0.51$ \\
\hline & 160 & $1.08 \pm 0.33$ & & 8 & $0.91 \pm 0.28$ \\
\hline & 320 & $0.51 \pm 0.37$ & & 16 & $0.49 \pm 0.33$ \\
\hline & 2 & $3.66 \pm 0.51$ & \multirow{5}{*}{$\begin{array}{c}3 \mathrm{CdSOB}_{4 \mathrm{~B}} \cdot 8 \mathrm{HB}_{2 \mathrm{~B}} \\
\mathrm{O}\end{array}$} & 0.2 & $4.50 \pm 0.65$ \\
\hline & 4 & $3.42 \pm 0.69$ & & 0.4 & $3.57 \pm 0.49$ \\
\hline \multirow{3}{*}{$\mathrm{ZnSOB}_{4 \mathrm{~B}} \cdot 7 \mathrm{HB}_{2 \mathrm{~B}} \mathrm{O}$} & 6 & $2.95 \pm 0.51$ & & 0.8 & $1.49 \pm 0.63$ \\
\hline & 8 & $1.53 \pm 0.46$ & & 1.6 & $0.35 \pm 0.29$ \\
\hline & 32 & $0.81 \pm 0.19$ & & 3.2 & $0.25 \pm 0.19$ \\
\hline
\end{tabular}

${ }^{\mathrm{PaP}}$ Growth was measured as the protein concentration after $72 \mathrm{~h}$. Values are means $\pm \mathrm{SD}(\mathrm{n} \geq 3)$.

\section{Fatty acid analysis}

Thermophilic archaea possess unique fatty acid composition which enable it to grow in high temperature (17), which is also an important method for phylogenetic study such as archaea identification and classification of (3).

Whole-cell fatty acid compositions were shown in Table 5. There were five groups of fatty acids found in strain YN25 by gas chromatograph. The predominant one was C16:0, 
accounting for $41.36 \%$ of the total fatty acids. The other four

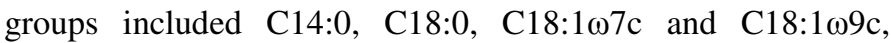
which account for $31.94 \%, 8.1 \%, 8.32 \%$ and $10.27 \%$ respectively. Strain YN25 had similar composition of membrane fatty acid with strain A. ambivalens JCM 9191 and A. brierleyi JCM 8954. However, compared with YN25, A.

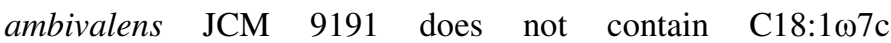
monounsaturated fatty acid while A. brierleyi JCM 8954 possesses a unique fatty acid-- $\mathrm{C} 16: 1 \omega 7 \mathrm{c} / 15$ iso $2 \mathrm{OH}$.
According to the characteristics of Alicyclobacillus, $\omega$ alicyclic acids are the predominant membrane fatty acids in this genus $(14,29)$. Membrane lipid composition of Metallosphaera sedula YN23 (accession number of GenBank: EF142855) was more complex than YN25. As shown in Table 5, strain YN25 was substantially different from Alicyclobacillus sendaiensis, Sulfolobus metallicus and Metallosphaera sedula. According to the analysis of fatty acid, strain YN25 was closed related to the genus Acidianus.

Table 5. Membrane fatty acid composition of strain YN25, related Acidianus species and three archaea (Data in each column are percentages of membrane fatty acids in a species, \%)

\begin{tabular}{|c|c|c|c|c|c|c|c|}
\hline Fatty acid & 1 & 2 & 3 & 4 & 5 & 6 & 7 \\
\hline $\mathrm{c} 14: 0$ & 31.94 & & & & 19.33 & 27.37 & 18.42 \\
\hline c15:0 & & & 0.2 & & & & \\
\hline c15: 0 iso & & 0.88 & 1.1 & 1.4 & & & \\
\hline c15: 0 anteiso & & & 1.5 & & & & \\
\hline $\mathrm{c} 16: 0$ & 41.36 & 3.45 & 4.9 & & 16.26 & 50.15 & 43.56 \\
\hline c16: 0 iso & & 6.69 & 1.6 & 1.4 & & & \\
\hline c17: 0 & & & 0.6 & & & & \\
\hline $\mathrm{c} 17: 0$ iso & & 5.55 & 4.5 & 1.9 & & & \\
\hline c17: 0 anteiso & & 4.80 & 4.5 & 2.3 & 10.27 & & \\
\hline c18:0 & 8.1 & 0.69 & 0.9 & & & 14.21 & 12.63 \\
\hline c18: 0 iso & & 1.87 & & & & & \\
\hline $\mathrm{c} 18: 1 \omega 7 \mathrm{c}$ & 8.32 & 76.07 & & & & & 6.96 \\
\hline $\mathrm{c} 18: 1 \omega 9 \mathrm{c}$ & 10.27 & & & & & 8.26 & 7.96 \\
\hline$\omega$-Cyclohexane C17: 0 & & & 44.1 & 78.0 & & & \\
\hline$\omega$-Cyclohexane C19: 0 & & & 30.2 & 16.0 & & & \\
\hline unknown 13.565 & & & & & 12.21 & & \\
\hline unknown 13.957 & & & & & 4.08 & & \\
\hline $15: 03 \mathrm{OH}$ & & & & & 28.39 & & \\
\hline $16: 1 \omega 7 \mathrm{c} / 15$ iso $2 \mathrm{OH}$ & $\cdot$ & & & & 5.47 & & 10.46 \\
\hline
\end{tabular}

1. Strain YN25; 2. Alicyclobacillus sendaiensis YNTC-1 (6); 3. Alicyclobacillus sendaiensis (29); 4. Ab. acidocaldarius ATCC 27009P ${ }^{\mathrm{TP}}$ (29); 5. Metallosphaera sedula YN23; 6. Acidianus ambivalens JCM 9191; 7. A. brierleyi JCM 8954

\section{Molecular phylogenetic analysis}

The phylogenetic position of the new isolate was evaluated by $16 \mathrm{~S}$ rRNA gene sequence information, in which a total of 1416 nucleotides were sequenced (accession number of GenBank EF522787). The nearest phylogenetic relative to the isolate was Acidianus manzaensis ATCC BAA 1057 with exactly $99 \%$ of similarity. A neighbour-joining phylogenetic tree was constructed based on the distance matrix data of the isolate and several reference archaea. As described in Figure 3, the species of Acidianus chosen were dividied into six groups based on the 16S rRNA gene sequences, and strain YN25 clustered with Acidianus manzaensis ATCC BAA 1057.

Based on morphological, biochemical, physiological characterizatics and the molecular biology analysis, strain YN25 could be classified into Acidianus manzaensis. 


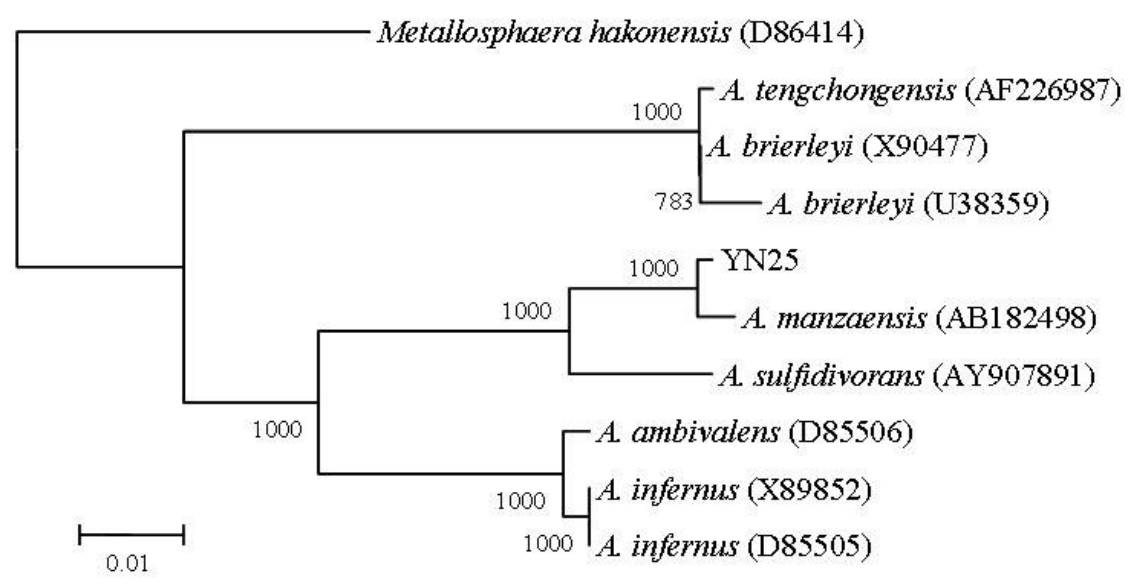

Figure 3. Distance-matrix tree showing phylogenetic affiliations of the new isolate YN25 and referenced archaea based on $16 \mathrm{~S}$ rRNA sequences. Bootstrap values obtained with 1000 bootstrap resamplings are given at branching points of interest. The DDBJ/EMBL/GenBank accession numbers of the 16S rRNA sequences used is shown in parentheses. Bar, 1 nucleotide stitutions per 100 nucleotides

\section{Bioleaching experiments}

The bioleaching results by Acidianus manzaensis YN25 were as shown in Figure 4. In the leaching process, where more than $70 \%$ copper was extracted during the first 16 days, the copper extraction ratio continuously increases with a final concentration of $7.16 \mathrm{~g} \cdot \mathrm{L}^{-1}$ after 24 days. Comparatively, almost no soluble copper was detected in sterile controls. This was the first report in bioleaching by the an Acidianus species.

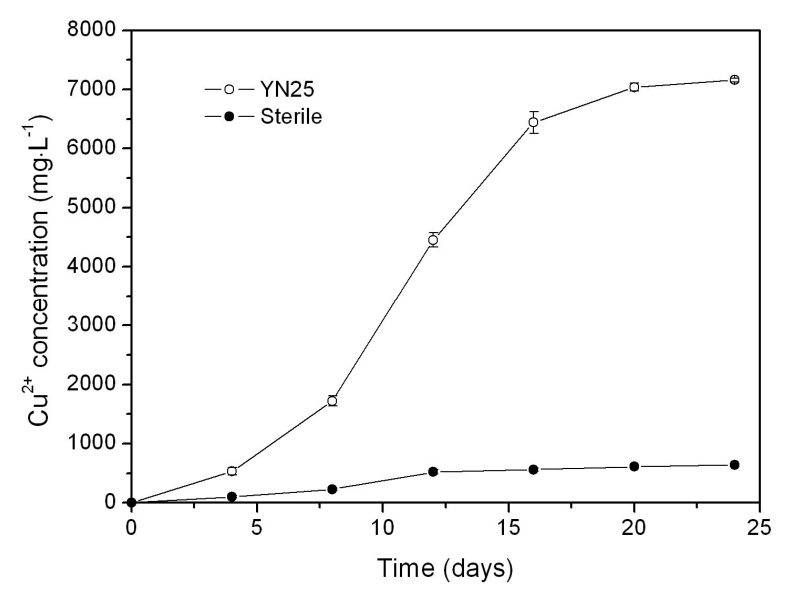

Figure 4. Chalcopyrite leached by Acidianus manzaensis YN25
As a thermophilic microbe, Acidianus manzaensis YN25 showed strong capacity of chalcopyrite bioleaching compared with moderate thermophiles (Acidithiobacillus caldus, Sulfobacillus thermosulfidooxidans, Sulfobacillus acidophilus, Leptospirillum ferriphilum and Ferroplasma thermophilum) $(11,30,33,34,35)$ or mesophiles (Leptospirillum ferrooxidans, Acidithiobacillus ferrooxidans, Acidithiobacillus thiooxidans, Acidithiobacillus albertensis) (5, 9, 27, 31). The sulfur particles formed during the bioleaching were readily to accumulate on the surface of solid phase and form passivation layer, which can significantly inhibit the contaction of solid and liquid phases thus hinder the leaching process $(10,24,25,28)$. Acidianus manzaensis YN25 showed strong capacity of oxidizing $\mathrm{FeP}^{2+\mathrm{P}}$ and $\mathrm{SP}^{0 \mathrm{P}}$ in our previous study. It can be inferred that, Acidianus manzaensis YN25 thriving at temperatures of $65 \square$, which is lethal to moderate thermophiles and mesophiles,could effectively limit passivation, consequently, leading to a better leaching kinetics.

Pure culture of Acidianus manzaensis was first discovered in 2007 by Yoshida et al, named Acidianus manzaensis strain NA-1 ${ }^{\mathrm{T}}$ (strain NA-1 ${ }^{\mathrm{T}}=$ NBRC $100595=$ ATCC BAA 1057). 
The strain isolated from a hot fumarole in Manza, Japan is a facultative autotrophic archaeon in both anaerobic and aerobic conditions (32). Acidianus manzaensis YN25 was the second strain of this species. Strain YN25 have new features in cell morphology, growth conditions and anaerobic metabolisms compared with Acidianus manzaensis ATCC BAA 1057, which could be relevant to its excellent leaching ability and prosperous prospective in industrial use.

\section{ACKNOWLEDGEMENTS}

This work was supported by the China National Basic Research Program (2010CB630902) and China National Nature Science Foundation (50974140).

\section{REFERENCES}

1. Acevedo, F.; Gentina, J.C.; Valencia, P. (2004). Optimization of pulp density and particle size in the biooxidation of a pyritic gold concentrate by Sulfolobus metallicus. World J. Microbiol. Biotechnol. 20(8), 865869.

2. Brierley, C.L.; Brierley, J.A. (1973). A chemoautotrophic and thermophilic microorganism isolated from an acid hot spring. Can. J. Microbiol. 19, 183-188.

3. Claus, H.; Akca, E.; Debaerdemaeker, T.; Evrard, C.; Declercq, J.P.; Konig, H. (2002). Primary structure of selected archaeal mesophilic and extremely thermophilic outer surface layer proteins. Syst. appl. microbiol. 25(1), 3-12.

4. Cytryn, E.; Minz, D; Oremland, R.S.; Cohen, Y. (2000). Distribution and diversity of archaea corresponding to the limnological cycle of a Hypersaline Stratified Lake (Solar Lake, Sinai, Egypt). Appl. Environ. Microbiol. 66(8), 3269-3276.

5. Dempers, C.J.N.; Breed, A.W.; Hansford, G.S. (2003). The kinetics of ferrous-iron oxidation by Acidithiobacillus ferrooxidans and Leptospirillum ferrooxidans: effect of cell maintenance. Biochem. Eng. J. 16(3), 337-346.

6. Ding, J.; He, H.; Zhang, C.; Yu, Y.; Qiu, G. (2008). Isolation and characterization of YNTC-1, a novel Alicyclobacillus sendaiensis strain. J. Cent. South Univ. T. 15(4), 508-514.

7. Dopson, M.; Lindstrom, E.B. (1999). Potential role of Thiobacillus caldus in arsenopyrite bioleaching. Appl. Environ. Microbiol. 65(1), 36-
40 .

8. Dopson, M.; Baker-Austin, C.; Hind, A.; Bowman, J.P,; Bond, P.L. (2004). Characterization of Ferroplasma isolates and Ferroplasma acidarmanus sp. nov., extreme acidophiles from acid mine drainage and industrial bioleaching environments. Appl. Environ. Microbiol. 70(4), 2079-2088.

9. Falco, L.; Pogliani, C.; Curutchet, G.; Donati, E. (2003). A comparison of bioleaching of covellite using pure cultures of Acidithiobacillus ferrooxidans and Acidithiobacillus thiooxidans or a mixed culture of Leptospirillum ferrooxidans and Acidithiobacillus thiooxidans. Hydrometallurgy 71(1-2), 31-36.

10. Fowler, T.A.; Crundwell, F.K. (1999). Leaching of zinc sulfide by Thiobacillus ferrooxidans: bacterial oxidation of the sulfur product layer increases the rate of zinc sulfide dissolution at high concentrations of ferrous ions. Appl. Environ. Microbiol. 65(12), 5285-5292.

11. Gao, J.; Zhang, C.G.; Wu, X.L.; Wang, H.H.; QIU, G.Z. (2007). Isolation and identification of a strain of Leptospirillum ferriphilum from an extreme acid mine drainage site. Ann. Microbiol. 57(2), 171-176.

12. Geng, A.; Soh, A.E.W.; Lim, C.J.; Loke, L.C.T. (2006). Isolation and characterization of a phenol-degrading bacterium from an industrial activated sludge. Appl. Microbiolm. Biotechnol. 71(5), 728-735.

13. Gomez, E.; Ballester, A.; Blazquez, M.L.; Gonzalez, F. (1999). Silvercatalysed bioleaching of a chalcopyrite concentrate with mixed cultures of moderately thermophilic microorganisms. Hydrometallurgy 51(1), 3746.

14. Goto, K.; Matsubara, H.; Mochida, K.; Matsumura, T.; Hara, Y.; Niwa, M.; Yamasato, K. (2002). Alicyclobacillus herbarius sp. nov., a novel bacterium containing omega-cycloheptane fatty acids, isolated from herbal tea. Int. J. Syst. Evol. Microbiol. 52(1), 109-113.

15. Hallberg, K.B.; Johnson, D.B. (2001). Biodiversity of acidophilic prokaryotes. Adv. appl. Microbiol. 49, 37-84.

16. He, Z.G.; Zhong, H.; Li, Y. (2004). Acidianus tengchongensis sp. nov., a new species of acidothermophilic archaeon isolated from an acidothermal spring. Curr. Microbiol. 48(2), 159-163.

17. Ivanov, I.T. (2002). Derivative conductometry profile of thermal alterations in cellular membranes-a possible relationship between membrane alterations, cellular proliferation capacity and maximum temperature of growth. J. Therm. Biol. 27(2), 137-149.

18. Jantzen, E.; Sonesson, A.; Tangen, T.; Eng, J. (1993). Hydroxy-fatty acid profiles of Legionella species: diagnostic usefulness assessed by principal component analysis. J. Clin. Microbiol. 31(6), 1413-1419.

19. Johnson, D.B.; Hallberg, K.B. (2003). The microbiology of acidic mine waters. Research in Microbiology 154(7), 466-473.

20. Plumb, J.J.; Haddad, C.M.; Gibson, J.A.E.; Franzmann, P.D. (2007) 
Acidianus sulfidivorans sp. nov., an extremely acidophilic, thermophilic archaeon isolated from a solfatara on Lihir Island, Papua New Guinea, and emendation of the genus description. Int. J. Syst. Evol. Microbiol. 57(7), 1418-1423.

21. Poulin, R.; Lawrence, R.W. (1996). Economic and environmental niches of biohydrometallurgy. Miner. Eng. 9(8), 799-810.

22. Rawlings, D.E. (2002). Heavy metal mining using microbes. Annu. Rev. Microbiol. 56, 65-91.

23. Rawlings, D.E.; Johnson, D.B. (2007). The microbiology of biomining: development and optimization of mineral-oxidizing microbial consortia. Microbiology 153(2), 315-324.

24. Rohwerder, T.; Gehrke, T.; Kinzler, K.; Sand, W. (2003). Bioleaching review part A. Appl. Microbiol. Biotechnol. 63(3), 239-248.

25. Schippers, A.; Sand, W. (1999). Bacterial leaching of metal sulfides proceeds by two indirect mechanisms via thiosulfate or via polysulfides and sulfur. Appl. Environ. Microbiol. 65(1), 319-321.

26. Segerer, A.; Neuner, A.; Kristjansson, J.K.; Stetter, K.O. (1986) Acidianus infernus gen. nov., sp. nov., and Acidianus brierleyi comb. nov.: facultatively aerobic, extremely acidophilic thermophilic sulfurmetabolizing archaebacteria. Int. J. Syst. Evol. Microbiol. 36(4), 559564.

27. Shi, S.; Fang, Z. (2004). Bioleaching of marmatite flotation concentrate by Acidithiobacillus ferrooxidans. Hydrometallurgy 75(1-4), 1-10.

28. Shi, S.; Fang, Z.; Ni, J. (2005). Bioleaching of marmatite flotation concentrate with a moderately thermoacidophilic iron-oxidizing bacterial strain. Miner. Eng. 18(11), 1127-1129.
29. Tsuruoka, N.; Isono, Y.; Shida, O.; Hemmi, H.; Nakayama, T.; Nishino, T. (2003). Alicyclobacillus sendaiensis sp. nov., a novel acidophilic, slightly thermophilic species isolated from soil in Sendai, Japan. Int. J. Syst. Evol. Microbiol. 53(4), 1081-1084.

30. Watling, H.R.; Perrot, F.A.; Shiers, D.W. (2008). Comparison of selected characteristics of Sulfobacillus species and review of their occurrence in acidic and bioleaching environments. Hydrometallurgy 93(1-2), 57-65.

31. Xia, J.L.; Peng, A.A.; He, H.; Yang, Y.; Liu, X.D.; Qiu, G.Z. (2007). A new strain Acidithiobacillus albertensis BY-05 for bioleaching of metal sulfides ores. T. Nonferr. Metal. Soc. 17(1), 168-175.

32. Yoshida, N.; Nakasato, M.; Ohmura, N.; Ando, A.; Saiki, H.; Ishii, M.; Igarashi, Y. (2006). Acidianus manzaensis sp. nov., a novel thermoacidophilic Archaeon growing autotrophically by the oxidation of $\mathrm{HB}_{2 \mathrm{~B}}$ with the reduction of $\mathrm{FeP}^{3+\mathrm{P}}$. Curr. Microbiol. 53(5), 406-411.

33. Zhang, R.; Xia, J.; Peng, J.; Zhang, Q.; Zhang, C.; Nie, Z.; Qiu, G. (2010). A new strain Leptospirillum ferriphilum YTW315 for bioleaching of metal sulfides ores. Trans. Nonferrous Met. Soc. China 20(1), 135-141.

34. Zhou, H.; Zhang, R.; Hu, P.; Zeng, W.; Xie, Y.; Wu, C.; Qiu, G. (2008). Isolation and characterization of Ferroplasma thermophilum sp. nov., a novel extremely acidophilic, moderately thermophilic archaeon and its role in bioleaching of chalcopyrite. J. Appl. Microbiol. 105(2), 591-601.

35. Zhou, Q.G.; Bo, F.; Hong Bo, Z.; Xi, L.; Jian, G.; Fei Fei, L.; Xin Hua, C. (2007). Isolation of a strain of Acidithiobacillus caldus and its role in bioleaching of chalcopyrite. World J. Microbiol. Biotechnol. 23(9), 1217-1225. 